University of Nebraska - Lincoln

DigitalCommons@University of Nebraska - Lincoln

Cob Removal Effect on Sediment and Runoff Nutrient Loss from a Silt Loam Soil

Brian J. Wienhold

University of Nebraska-Lincoln, Brian.Wienhold@ars.usda.gov

John E. Gilley

USDA-ARS, john.gilley@ars.usda.gov

Follow this and additional works at: https://digitalcommons.unl.edu/usdaarsfacpub

Wienhold, Brian J. and Gilley, John E., "Cob Removal Effect on Sediment and Runoff Nutrient Loss from a Silt Loam Soil" (2010). Publications from USDA-ARS / UNL Faculty. 1187.

https://digitalcommons.unl.edu/usdaarsfacpub/1187

This Article is brought to you for free and open access by the U.S. Department of Agriculture: Agricultural Research Service, Lincoln, Nebraska at DigitalCommons@University of Nebraska - Lincoln. It has been accepted for inclusion in Publications from USDA-ARS / UNL Faculty by an authorized administrator of DigitalCommons@University of Nebraska - Lincoln. 


\title{
Cob Removal Effect on Sediment and Runoff Nutrient Loss from a Silt Loam Soil
}

\author{
Brian J. Wienhold* and John E. Gilley
}

\begin{abstract}
The cob fraction of corn (Zea mays L.) residue has been identified as a potential feedstock for ethanol production. However, the role of the cob in soil and water conservation is largely unknown. A rainfall simulator study was conducted in an irrigated corn field in Nebraska having replicated strips where corn residue was removed $\left(6.0 \pm 1.0 \mathrm{Mg} \mathrm{ha}^{-1}\right.$ residue remaining, $49.5 \%$ cover) or retained $\left(12.9 \pm 1.0 \mathrm{Mg} \mathrm{ha}^{-1}\right.$ residue remaining, $77 \%$ cover). Duplicate plots were installed in each strip and cobs were removed from one and retained in the other. Simulated rainfall was applied for $30 \mathrm{~min}$ at a mean rate of $83 \mathrm{~mm} \mathrm{~h}$ to plots at antecedent moisture and $24 \mathrm{~h}$ later at near saturated soil moisture conditions. Time to initiate runoff, runoff and sediment loss, and water quality parameters were measured. Residue removal reduced the time to initiate runoff $(195.9 \pm 1.0 \mathrm{vs} .239 .5 \pm 4.8 \mathrm{~s})$ and increased sediment loss $\left(0.36 \pm 0.02 \mathrm{Mg} \mathrm{ha}^{-1} \mathrm{vs} .0 .27 \pm 0.01 \mathrm{Mg} \mathrm{ha}^{-1}\right)$. Cob removal reduced time to initiate runoff during the antecedent run but not during the saturated run. Residue removal and rainfall treatment (antecedent vs. saturated) affected runoff water quality parameters $\left(\mathrm{NO}_{3}-\mathrm{N}\right.$ concentration, $\mathrm{pH}$, soluble $\mathrm{P}$ concentration, and $\mathrm{NO}_{3}-\mathrm{N}$ loss). Cob removal did not affect runoff, sediment loss, runoff $\mathrm{pH}, \mathrm{NO}_{3}-\mathrm{N}, \mathrm{NH}_{4}-\mathrm{N}$, or soluble $\mathrm{P}$ loss. Cob removal when adequate stover was retained did not negatively affect erosion and runoff nutrient loss at this site.
\end{abstract}

$\mathrm{C}$ ONVERSION OF CROP RESIDUE to ethanol has been proposed as a replacement for a portion of the fossil energy currently used for transportation (Perlack et al., 2005). Early estimates of available residue and references to crop residue as trash or waste raised concerns in the soil and water conservation community (Lal, 2004). Concerns associated with crop residue removal included loss of fertilizer nutrients contained in the residue, increased soil compaction associated with additional field operations, increased susceptibility to wind and water erosion, and a decrease in soil organic matter (Wilhelm et al., 2004).

These concerns resulted in efforts to estimate the amount of biomass that could be harvested without adverse soil and water conservation impacts. Graham et al. (2007) conducted an analysis to estimate the cost and availability of stover that included constraints for protection against wind and water erosion, conservation of soil moisture, and the cost of fertilizer nutrients. Their analysis did not include a constraint for maintaining soil organic matter. This analysis concluded that $\sim 30 \%$ of corn stover was available as a sustainable feedstock. Johnson et al. (2006) used data from available residue removal studies to provide initial estimates for residue requirements

USDA-ARS, Agroecosystem Management Research Unit, Lincoln, NE 68583. Received 30 Apr. 2010. ${ }^{*}$ Corresponding author (Brian.Wienhold@ars.usda.gov).

Published in Agron. J. 102:1448-1452 (2010)

Published online 2 Aug. 2010

doi:10.2134/agronj2010.0202

Copyright (C) 2010 by the American Society of Agronomy, 5585 Guilford Road, Madison, WI 53711. All rights reserved. No part of this periodical may be reproduced or transmitted in any form or by any means, electronic or mechanical, including photocopying, recording, or any information storage and retrieval system, without permission in writing from the publisher. for maintaining soil organic carbon. They concluded that the amount of corn residue that needed to be retained increased as tillage intensity increased and was greater for corn-soybean rotations than for continuous corn. Wilhelm et al. (2007) used the estimates of Johnson et al. (2006) to estimate residue retention rates for maintaining soil organic matter, the second version of the Revised Universal Soil Loss Equation to estimate residue retention rates to protect against water erosion, and the Wind Erosion Prediction System to estimate residue retention rates to protect against wind erosion for 10 common soils in the U.S. Corn Belt. Results indicated that residue retention rates increased as tillage intensity increased, were greater for cornsoybean systems that continuous corn, and the amount of residue needed to maintain soil organic matter was much greater than that needed to protect against wind and water erosion.

One component of corn residue that is being evaluated as a feedstock for biofuels is the cob. From 2005 to 2009 the United States produced an average of 257 million $\mathrm{Mg}$ of corn grain (http://www.nass.usda.gov/index.asp [verified 15 July 2010]). Cob mass is 17 to $20 \%$ of the grain mass (Halvorson and Johnson, 2009; Varvel and Wilhelm, 2008). Cob biomass produced between 2005 and 2009 represents from 43.8 to 51.5 million $\mathrm{Mg}$ of potential feedstock for energy related uses. As technology for cellulosic biofuel production comes on line the cob fraction could be used to produce 14.4 to 16.9 billion $\mathrm{L}$ of ethanol assuming a conversion efficiency of $0.329 \mathrm{~L} \mathrm{~kg}^{-1}$ (Kim and Dale, 2004).

Conversion of a cellulosic feedstock to ethanol is less efficient (0.329 $\mathrm{L} \mathrm{kg}^{-1}$; Kim and Dale, 2004) than conversion of corn grain to ethanol $\left(0.432 \mathrm{~L} \mathrm{~kg}^{-1}\right.$; Turhollow et al., 1988). In addition, the cob mass produced on an area of land is 17 to $20 \%$ that of the corn grain (Halvorson and Johnson, 2009; Varvel and Wilhelm, 2008). Assuming corn is the sole feedstock source a cellulosic ethanol plant colocated with a grain ethanol plant 
having the same capacity would require cobs from 6.6 to 7.9 times the production area as the grain. While feedstock haul distances will be greater for cellulosic sources, the cob fraction is more dense and lends itself to transportation and storage more readily than does the leaf and stem fractions. Commercial companies are developing the technology to convert cob biomass into ethanol; develop technologies to facilitate collection, transport, and storage of cob biomass; and a cellulosic ethanol plant designed to use the cob fraction is being planned for a site near Emmetsburg, IA (http://www.projectliberty.com/ [verified 15 July 2010]). However, little is known about the role of the cob component in soil and water conservation.

Crop residue provides surface cover and protects soil from raindrop impact reducing sediment loss during precipitation events. As surface cover decreases sediment loss increases (e.g., Gilley et al., 1986). Gilley et al. (1986) developed regression equations for estimating soil cover based on residue biomass. These equations treat all residues equally even though residue components differ greatly in density. The cob fraction of corn residue is denser than other residue components and comprises 14 to $25 \%$ of stover biomass in adequately fertilized fields (Halvorson and Johnson, 2009). On a mass basis harvesting the cob fraction is expected to have little effect on erosion potential. In contrast, in fields where residue is being removed for other uses (e.g., feed component in livestock operations using distiller's byproducts) the cob fraction may play an important role in soil conservation.

The objective of this study was to compare sediment and runoff nutrient loss from plots having cobs removed or retained. The study was conducted in a producer field having strips where corn stover was harvested or retained. These treatments represent residue management practices ranging from complete retention to harvesting with and without cobs and represent a number of current and proposed management scenarios.

\section{MATERIALS AND METHODS}

The runoff study was conducted in a producer field in York county Nebraska (4056' N, 97º34' W). Soils at the site were Hastings silt loam (fine, smectitic, mesic Udic Argiustolls) and Hord silt loam (fine-silty, mixed, superactive, mesic Cumulic Haplustolls). Slopes within the field range from 0 to $11 \%$. These soils developed on loess parent material and are susceptible to wind and water erosion. The field was under continuous corn production using ridge tillage. Precipitation was supplemented with irrigation provided through two center pivots. Agronomic decisions were made by the producer and were typical for the area. Grain yields ( $155 \mathrm{~g} \mathrm{~kg}^{-1}$ moisture) were $13.18 \pm 0.30 \mathrm{Mg} \mathrm{ha}^{-1}$ in $2006,14.21 \pm 0.50 \mathrm{Mg} \mathrm{ha}^{-1}$ in $2007,15.78 \pm 0.44 \mathrm{Mg} \mathrm{ha}^{-1}$ in 2008 , and $15.82 \pm 0.29 \mathrm{Mg} \mathrm{ha}^{-1}$ in 2009 . This field has been part of a residue removal study since 2006. Two treatments, residue removed or residue retained, were applied to 28-row wide (28 m) strips. In the residue removed treatment, crop residue was windrowed following grain harvest and rolled into round bales which were removed from the field. Treatments were randomly assigned to strips within four blocks that run the length of the field.

Within each strip of the residue removal study, two 0.75 by $2.0 \mathrm{~m}$ runoff plots were established in a section of the field where the Hastings soil was present on a $7 \%$ slope. Plots were established by installing metal borders along the three upslope sides of the plot. A metal trough was installed on the downslope end
Table I. Select soil properties for the 0 - to $5-\mathrm{cm}$ depth of the Hastings soil at the York County, Nebraska residue removal site.

\begin{tabular}{lc}
\hline \multicolumn{1}{c}{ Soil property } & Value \\
\hline $\mathrm{NO}_{3}-\mathrm{N}$ & $1.88 \pm 0.47 \mathrm{mg} \mathrm{kg}^{-1}$ \\
$\mathrm{NH}_{4}-\mathrm{N}$ & $0.69 \pm 0.10 \mathrm{mg} \mathrm{kg}^{-1}$ \\
Electrical conductivity & $0.36 \pm 0.02 \mathrm{dS} \mathrm{m}^{-1}$ \\
$\mathrm{pH}$ & $6.11 \pm 0.09$ \\
$\mathrm{PO}_{4}-\mathrm{P}$ & $41.87 \pm 6.39 \mathrm{mg} \mathrm{kg}^{-1}$ \\
Water content & $280 \pm 10 \mathrm{~g} \mathrm{~kg}^{-1}$ \\
\hline
\end{tabular}

of the plot to direct runoff and sediment to a collection bucket. The long axis of the plots was perpendicular to the slope. In this area of the field the crop rows were also perpendicular to the slope. All residue (attached residue was clipped as close to the soil surface as possible) was removed from each runoff plot, weighed, and returned to the plot. The cob component of the residue was retained in one randomly selected plot and removed from the other. Soil cover was estimated using regressions relating residue mass to soil cover developed by Gilley et al. (1986).

A soil sample, 0 - to 15 -cm depth, was collected next to each runoff plot. Water content was determined by measuring mass lost during drying at $105^{\circ} \mathrm{C}$ for $48 \mathrm{~h}$ (Gardner, 1986). Electrical conductivity and $\mathrm{pH}$ was determined by adding distilled water on a $1: 1 \mathrm{w} / \mathrm{w}$ basis to $10 \mathrm{~g}$ of air-dried soil, electrical conductivity of the soil slurry was determined using a conductivity meter (Rhoades, 1982), and $\mathrm{pH}$ was then determined using a glass electrode (McLean, 1982). Inorganic $\mathrm{N}$ in $1 \mathrm{M} \mathrm{KCl}$ extracts was measured colorimetrically using a Lachat flow injection ion analyzer (Zellweger Analytics, Lachat Instruments Div., Milwaukee, WI). Nitrate$\mathrm{N}$ was determined using the $\mathrm{Cd}$ reduction method (Mulvaney, 1996). Extractable $P$ was determined using the method of Bray and Kurtz (1945) with P concentration determined spectrophotometrically at $882 \mathrm{~nm}$ using the phosphomolybdate blue method (Murphy and Riley, 1962). Select soil properties were similar between the residue retained and residue removed treatments and mean values for the site are presented in Table 1.

Simulated rainfall was applied to the paired plots using a portable rainfall simulator (Humphry et al., 2002). Rainfall was applied for $30 \mathrm{~min}$ at a design rate of $70 \mathrm{~mm} \mathrm{~h}^{-1}$. Actual rainfall amounts were measured in four rain gauges placed along the outer edges of the two plots. Plots received rainfall at antecedent soil moisture content (Table 1) and $24 \mathrm{~h}$ later at near saturated soil moisture content. No natural precipitation was received during this study. For each rainfall event the time from rainfall initiation to runoff initiation was determined. Runoff from each plot was weighed, agitated, and two samples were taken for water quality analysis and two samples were taken to determine sediment loss. Runoff mass and plot dimensions were used to calculate runoff depth. Water quality samples were filtered and analyzed for dissolved P using the phosphomolybdate blue method (Murphy and Riley, 1962), $\mathrm{NO}_{3}-\mathrm{N}$ and $\mathrm{NH}_{4}-\mathrm{N}$ using the $\mathrm{Cd}$ reduction method (Mulvaney, 1996) using a Lachat system (Zellweger Analytics, Milwaukee, WI), $\mathrm{pH}$ was determined using a glass electrode (McLean, 1982), and electrical conductivity was determined using a conductivity meter (Rhoades, 1982). Sediment samples were dried at $105^{\circ} \mathrm{C}$ and weighed to determine sediment content.

The experiment had a split-split plot randomized block design where residue removal was the main plot, cob removal was the subplot, and rainfall application was a repeated measure. Runoff 
Table 2. Time to initiate runoff as a function of rainfall and cob removal treatment at the York County, Nebraska residue removal site.

\begin{tabular}{lccc}
\hline Cob removal & \multicolumn{2}{c}{ Rainfall treatment } & \multirow{2}{*}{ Mean } \\
\cline { 2 - 3 } \multicolumn{1}{c}{ treatment } & Antecedent & Saturated & \\
\cline { 2 - 3 } Retained & $242.7 \pm 4.0 \mathrm{Aa} \dagger$ & $207.7 \pm 4.0 \mathrm{Ba}$ & $225.2 \pm 2.8 \mathrm{a}$ \\
Removed & $215.0 \pm 4.0 \mathrm{Ab}$ & $205.3 \pm 4.0 \mathrm{Aa}$ & $210.1 \pm 2.8 \mathrm{~b}$ \\
Mean & $228.8 \pm 2.8 \mathrm{~A}$ & $206.5 \pm 2.8 \mathrm{~B}$ & \\
\hline
\end{tabular}

† Mean \pm Standard Error. Means within a row followed by different uppercase letters are different at $P<0.05$. Means within a column followed by different lowercase letters are different at $P<0.05$.

and water quality measures were compared among treatments using a split-split plot randomized block repeated measures model in PROC MIXED of SAS (Littell et al., 1996). Differences were declared significant at the 0.05 probability level. Differences among means were determined by pair-wise comparisons made with the DIFF option of the LSMEANS statement.

\section{RESULTS AND DISCUSSION}

Rainfall applied $(41.5 \pm 0.5 \mathrm{~mm})$ was similar for all plots. Time to initial runoff exhibited a residue removal treatment effect $(p=0.002)$ and a cob removal treatment by rainfall treatment interaction $(p=0.034)$. Runoff began sooner after rainfall was initiated in residue removed plots $(195.9 \pm 1.0 \mathrm{~s})$ than in residue retained plots $(239.5 \pm 4.8 \mathrm{~s})$. Others have also reported an increase in time to initiate runoff as residue amounts increase (Blanco-Canqui et al., 2009). The larger amounts of residue in the residue retained plots likely intercepted more rainfall before runoff could begin. The cob treatment $\times$ rainfall treatment interaction resulted when runoff began sooner in cob-removed plots than in cob-retained plots during the initial run but was similar between treatments in the saturated run (Table 2). During the initial run the cobs likely absorbed a portion of the applied rain and delayed runoff while in the saturated run the cobs absorbed little additional applied rain and did not affect the time for runoff to begin.

Depth of runoff was similar among plots and rainfall treatments $(2.6 \pm 0.1 \mathrm{~mm})$ and represents $6 \%$ of the rainfall applied. In contrast, sediment loss was affected by residue removal ( $p=0.03$ ) with $30 \%$ more sediment being lost from plots having residue removed $\left(0.36 \pm 0.02 \mathrm{Mg} \mathrm{ha}^{-1}\right)$ than in plots where residue was retained $\left(0.27 \pm 0.01 \mathrm{Mg} \mathrm{ha}^{-1}\right)$. Cob removal did not affect sediment loss. Corn residue in the residue retained strips was $12.9 \pm 1.0 \mathrm{Mg} \mathrm{ha}^{-1}$ and in the residue removed strips was $6.0 \pm 1.0 \mathrm{Mg} \mathrm{ha}^{-1}$. Residue retained plots had an estimated surface cover of $77.0 \%$ compared to $49.5 \%$ in the residue removed plots. Increased surface cover in the residue retained plots reduced soil exposure to rainfall impact which is the primary mechanism for soil detachment (Mannering and Meyer, 1963).

Water quality measures differed in their response to the treatments imposed in this study. Runoff $\mathrm{NO}_{3}-\mathrm{N}$ concentration differed between the residue removal treatments $(p=0.0003)$ being greater in the residue removed treatment $\left(8.8 \pm 0.1 \mathrm{mg} \mathrm{L}^{-1}\right)$ than in the residue retained treatment $\left(8.5 \pm 0.1 \mathrm{mg} \mathrm{L}^{-1}\right)$. Runoff $\mathrm{NH}_{4}-\mathrm{N}$ concentration was low $\left(0.01 \pm 0.008 \mathrm{mg} \mathrm{L}^{-1}\right)$ and was similar among the treatments. Water soluble $\mathrm{P}$ concentration exhibited a residue treatment by cob treatment $\times$ rainfall treatment interaction $(p=0.0007)$. During the initial rainfall event crop residue removal increased water soluble $\mathrm{P}$ concentration in both cob treatments. In the saturated rainfall event water soluble $\mathrm{P}$ concentration was greater in the residue removal treatment than in the residue retained treatment and this effect was greater when cobs were retained than when cobs were removed (Table 3). Runoff electrical conductivity was similar among treatments $\left(0.80 \pm 0.004 \mathrm{dS} \mathrm{m}^{-1}\right)$. Runoff $\mathrm{pH}$ differed between rainfall treatments $(p=0.0007)$ and was greater in the saturated runoff treatment $(7.56 \pm 0.01)$ than in the initial runoff treatment $(7.48 \pm 0.01)$. While differences in $\mathrm{pH}$ values are statistically significant, a difference of $0.08 \mathrm{pH}$ units is of little practical importance and the difference was likely detected because this water quality parameter exhibited little variation among samples (coefficient of variation $=1.3 \%$ ).

On an area basis, $\mathrm{NO}_{3}-\mathrm{N}$ loss differed among rainfall treatments $(p=0.03)$ and was greater during the saturated rainfall treatment $\left(2.31 \pm 0.07 \mathrm{~kg} \mathrm{ha}^{-1}\right)$ than in the initial rainfall treatment $\left(1.99 \pm 0.07 \mathrm{~kg} \mathrm{ha}^{-1}\right)$. Loss of $\mathrm{NH}_{4}-\mathrm{N}\left(0.002 \pm 0.001 \mathrm{~kg} \mathrm{ha}^{-1}\right)$ and water soluble $\mathrm{P}$ $\left(0.07 \pm 0.004 \mathrm{~kg} \mathrm{ha}^{-1}\right)$ was similar among treatments. Mass of nutrients lost in runoff and lack of residue removal affect on runoff nutrient loss agrees with the results reported by Blanco-Canqui et al. (2009) for a single rainfall application to no-tillage wheat (Triticum aestivum $\mathrm{L}$.) over a range of residue removal rates.

There were no significant correlations among application amount, time to initial runoff, depth of runoff, and sediment loss (Table 4). Lack of correlation among these variables confirms that residue treatments caused the observed differences in time to initial runoff and sediment loss discussed above rather than variation in applied rainfall. Applied rainfall was weakly correlated with $\mathrm{NH}_{4}-\mathrm{N}$ concentration in runoff, $\mathrm{NH}_{4}-\mathrm{N}$ loss on an area basis, and runoff $\mathrm{pH}$. Time to initiate runoff was weakly correlated with runoff $\mathrm{pH}$. Depth of runoff was positively correlated with mass of $\mathrm{NO}_{3}-\mathrm{N}$ and water soluble $\mathrm{P}$ loss and confirms that as runoff increases loss of these nutrients also increases (Andraski and Bundy, 2003). Sediment

Table 3. Runoff $P$ concentration as a function of rainfall, cob, and residue treatments at the York County, Nebraska residue removal site.

\begin{tabular}{|c|c|c|c|c|c|c|}
\hline \multirow{3}{*}{$\begin{array}{c}\text { Residue } \\
\text { treatment }\end{array}$} & \multicolumn{6}{|c|}{ Rainfall treatment } \\
\hline & \multicolumn{3}{|c|}{ Antecedent cob treatment } & \multicolumn{3}{|c|}{ Saturated cob treatment } \\
\hline & Retained & Removed & Mean & Retained & Removed & Mean \\
\hline & \multicolumn{4}{|c|}{$\mathrm{PO}_{4}-\mathrm{P}$ concentration, $\mathrm{mg} \mathrm{L}^{-1}$} & & \\
\hline Retained & $0.29 \pm 0.01$ & $0.30 \pm 0.01$ & $0.30 \pm 0.0 \mathrm{IAb}$ & $0.23 \pm 0.01$ & $0.24 \pm 0.01$ & $0.24 \pm 0.0 \mathrm{IBb}$ \\
\hline Removed & $0.36 \pm 0.01$ & $0.34 \pm 0.01$ & $0.35 \pm 0.0 \mathrm{IAa}$ & $0.30 \pm 0.01$ & $0.22 \pm 0.01$ & $0.26 \pm 0.01 \mathrm{Ba}$ \\
\hline Mean & $0.33 \pm 0.0 \mathrm{IA} t$ & $0.32 \pm 0.01 \mathrm{~A}$ & & $0.27 \pm 0.01 \mathrm{~B}$ & $0.23 \pm 0.01 \mathrm{C}$ & \\
\hline
\end{tabular}

$\dagger$ Mean \pm Standard Error. Means within a row followed by different uppercase letters are different at $P<0.05$. Means within a column followed by different lowercase letters are different at $P<0.05$. 
Table 4. Correlation among select runoff parameters at the York County, Nebraska residue removal site.

\begin{tabular}{|c|c|c|c|c|c|c|c|c|c|c|c|c|}
\hline Variable $†$ & App. & time & Depth & Sed. loss & $\mathrm{NO}_{3}-\mathrm{N}$ & $\mathbf{N H}_{4}-\mathbf{N}$ & EC & $\mathrm{pH}$ & $\mathrm{PO}_{4}-\mathrm{P}$ & $\mathrm{NO}_{3}-\mathrm{N}$ loss & $\mathrm{NH}_{4}-\mathrm{N}$ loss & $\mathrm{PO}_{4}-\mathrm{P}$ loss \\
\hline App. & I & $\begin{array}{c}0.05 \ddagger \\
\mathrm{ns}\end{array}$ & $\begin{array}{c}-0.05 \\
\mathrm{~ns}\end{array}$ & $\begin{array}{c}-0.29 \\
\mathrm{~ns}\end{array}$ & $\begin{array}{c}-0.10 \\
\mathrm{~ns}\end{array}$ & $\begin{array}{c}0.40 \\
*\end{array}$ & $\begin{array}{c}-0.03 \\
\mathrm{~ns}\end{array}$ & $\begin{array}{c}-0.53 \\
* *\end{array}$ & $\begin{array}{c}-0.09 \\
\mathrm{~ns}\end{array}$ & $\begin{array}{c}-0.15 \\
\mathrm{~ns}\end{array}$ & $\begin{array}{c}0.44 \\
* *\end{array}$ & $\begin{array}{c}-0.17 \\
\mathrm{~ns}\end{array}$ \\
\hline Time & & 1 & $\begin{array}{c}-0.16 \\
\mathrm{~ns}\end{array}$ & $\begin{array}{c}-0.06 \\
\mathrm{~ns}\end{array}$ & $\begin{array}{c}0.15 \\
\mathrm{~ns}\end{array}$ & $\begin{array}{c}0.02 \\
n s\end{array}$ & $\begin{array}{c}-0.08 \\
n s\end{array}$ & $\begin{array}{c}-0.37 \\
*\end{array}$ & $\begin{array}{c}0.28 \\
\mathrm{~ns}\end{array}$ & $\begin{array}{c}-0.09 \\
\mathrm{~ns}\end{array}$ & $\begin{array}{c}0.05 \\
n s\end{array}$ & $\begin{array}{c}0.06 \\
n s\end{array}$ \\
\hline Depth & & & I & $\begin{array}{c}0.18 \\
\mathrm{~ns}\end{array}$ & $\begin{array}{c}-0.08 \\
\mathrm{~ns}\end{array}$ & $\begin{array}{c}-0.27 \\
\mathrm{~ns}\end{array}$ & $\begin{array}{c}-0.04 \\
\mathrm{~ns}\end{array}$ & $\begin{array}{c}0.34 \\
\text { ns }\end{array}$ & $\begin{array}{c}-0.33 \\
\mathrm{~ns}\end{array}$ & $\begin{array}{c}0.92 \\
* * *\end{array}$ & $\begin{array}{c}-0.23 \\
\mathrm{~ns}\end{array}$ & $\begin{array}{c}0.69 \\
* * *\end{array}$ \\
\hline Sed. & & & & I & $\begin{array}{c}0.21 \\
\mathrm{~ns}\end{array}$ & $\begin{array}{c}-0.26 \\
\mathrm{~ns}\end{array}$ & $\begin{array}{c}0.20 \\
\text { ns }\end{array}$ & $\begin{array}{c}0.36 \\
*\end{array}$ & $\begin{array}{c}0.20 \\
\mathrm{~ns}\end{array}$ & $\begin{array}{c}0.24 \\
\mathrm{~ns}\end{array}$ & $\begin{array}{c}-0.30 \\
\mathrm{~ns}\end{array}$ & $\begin{array}{c}0.35 \\
*\end{array}$ \\
\hline $\mathrm{NO}_{3}-\mathrm{N}$ & & & & & I & $\begin{array}{c}0.08 \\
\text { ns }\end{array}$ & $\begin{array}{l}0.69 \\
* * *\end{array}$ & $\begin{array}{c}-0.18 \\
\mathrm{~ns}\end{array}$ & $\begin{array}{c}0.15 \\
\text { ns }\end{array}$ & $\begin{array}{c}0.31 \\
\mathrm{~ns}\end{array}$ & $\begin{array}{c}0.06 \\
\text { ns }\end{array}$ & $\begin{array}{c}0.04 \\
\text { ns }\end{array}$ \\
\hline $\mathrm{NH}_{4}-\mathrm{N}$ & & & & & & I & $\begin{array}{c}0.27 \\
\mathrm{~ns}\end{array}$ & $\begin{array}{c}-0.58 \\
* *\end{array}$ & $\begin{array}{c}0.34 \\
\text { ns }\end{array}$ & $\begin{array}{c}-0.25 \\
\mathrm{~ns}\end{array}$ & $\begin{array}{l}0.99 \\
* * *\end{array}$ & $\begin{array}{c}-0.10 \\
\mathrm{~ns}\end{array}$ \\
\hline EC & & & & & & & I & $\begin{array}{c}-0.23 \\
\mathrm{~ns}\end{array}$ & $\begin{array}{c}0.43 \\
* *\end{array}$ & $\begin{array}{c}0.22 \\
\mathrm{~ns}\end{array}$ & $\begin{array}{c}0.24 \\
\mathrm{~ns}\end{array}$ & $\begin{array}{c}0.27 \\
n s\end{array}$ \\
\hline $\mathrm{pH}$ & & & & & & & & I & $\begin{array}{c}-0.27 \\
\mathrm{~ns}\end{array}$ & $\begin{array}{c}0.28 \\
\mathrm{~ns}\end{array}$ & $\begin{array}{c}-0.54 \\
* *\end{array}$ & $\begin{array}{c}0.18 \\
\text { ns }\end{array}$ \\
\hline $\mathrm{PO}_{4}-\mathrm{P}$ & & & & & & & & & I & $\begin{array}{c}-0.27 \\
\mathrm{~ns}\end{array}$ & $\begin{array}{c}0.31 \\
\mathrm{~ns}\end{array}$ & $\begin{array}{c}0.44 \\
* *\end{array}$ \\
\hline $\mathrm{NO}_{3}-\mathrm{N}$ Loss & & & & & & & & & & I & $\begin{array}{c}-0.21 \\
\mathrm{~ns}\end{array}$ & $\begin{array}{c}0.67 \\
* * *\end{array}$ \\
\hline $\mathrm{NH}_{4}-\mathrm{N}$ Loss & & & & & & & & & & & I & $\begin{array}{c}-0.08 \\
\mathrm{~ns}\end{array}$ \\
\hline $\mathrm{PO}_{4}-\mathrm{P}$ Loss & & & & & & & & & & & & 1 \\
\hline
\end{tabular}

* Significance at $P<0.05$.

** Significance at $P<0.01$.

*** Significance at $P<0.001$.

† Variables are: App., simulated rainfall applied (mm); Time, time to initial runoff (s); Depth, runoff depth (mm); Sed., sediment loss (kg ha ${ }^{-1}$ ); $N O_{3}-\mathrm{N}$, nitrate $\mathrm{N}$ concentration in runoff; $\mathrm{NH}_{4}-\mathrm{N}$, ammonium $\mathrm{N}$ concentration in runoff; $\mathrm{EC}$, electrical conductivity $\left(\mathrm{dS} \mathrm{m}^{-1}\right) ; \mathrm{PO}_{4}-\mathrm{P}$, phosphate-P concentration in runoff; $\mathrm{NO} \mathrm{O}_{3}-\mathrm{N}$ loss, nitrate $\mathrm{N}$ loss ( $\left.\mathrm{kg} \mathrm{ha}^{-1}\right) ; \mathrm{NH}_{4}-\mathrm{N}$ loss, ammonium $\mathrm{N}$ loss $\left(\mathrm{kg} \mathrm{ha}^{-1}\right) ; \mathrm{PO}_{4}-\mathrm{P}$ loss, phosphate- $\mathrm{P}$ loss $\left(\mathrm{kg} \mathrm{ha}^{-1}\right)$.

$\ddagger$ Correlation coefficient ns is nonsignificant.

loss was weakly correlated with runoff $\mathrm{pH}$ and mass of water soluble P loss. Runoff electrical conductivity was positively correlated with runoff $\mathrm{NO}_{3}-\mathrm{N}$ and soluble $\mathrm{P}$ concentration. In nonsaline soils electrical conductivity often correlates well with these nutrient concentrations (Smith and Doran, 1996). Runoff $\mathrm{pH}$ was weakly correlated with $\mathrm{NH}_{4}-\mathrm{N}$ concentration in runoff and $\mathrm{NH}_{4}-\mathrm{N}$ loss. Concentration for $\mathrm{NH}_{4}-\mathrm{N}$ and loss of $\mathrm{NH}_{4}-\mathrm{N}$ and soluble $\mathrm{P}$ concentration and loss of soluble $\mathrm{P}$ were positively correlated. These nutrients were present in the highest amounts in the soil (Table 1) and were available for transport in runoff from the plots as discussed above.

This study was conducted on a loess-derived soil that is susceptible to erosion. The conditions used in this study represent an extreme case which will facilitate extrapolating the results to less extreme conditions. Baling of residue with commercial equipment removed $6.9 \mathrm{Mg} \mathrm{ha}^{-1}$ of crop residue and represents the maximum removal rate that is practical with existing equipment. The residue removed is also close to the harvestable amount calculated using equations developed to determine the amount of residue that must be retained to maintain soil organic C (Johnson et al., 2007). Removal of this amount of residue resulted in a $30 \%$ increase in sediment loss. This supports the argument that harvesting residue from soils that are susceptible to erosion may not be sustainable (Wilhelm et al., 2004). In contrast, removal of the cob fraction did not increase sediment loss from this soil. Estimates for the amount of residue needed to sustain soil biota and maintain soil organic $\mathrm{C}$ is greater than that needed to protect the soil from erosion (Wilhelm et al., 2007). While the role of the cob fraction in $\mathrm{C}$ and nutrient cycling has not been determined, from a soil and water conservation perspective, the cob fraction may represent a crop residue component that can be harvested without negatively affecting the soil resource.

Graham et al. (2007) estimated harvestable stover amounts based on average corn yield, harvest index, and excluding areas where crop residue was needed to protect against wind and water erosion or to conserve soil water. They concluded that residue could be harvested from $\sim 30 \%$ of land planted to corn. Results presented above demonstrated that removal of the cob fraction of residue did not increase sediment loss at a site susceptible to water erosion and it is likely that if the remainder of the residue is retained the cob fraction could be harvested from much more than $30 \%$ of the planted area. There are areas where production is low or the potential for wind and water erosion is so great that all residue needs to be retained so it is not realistic to expect cobs to be harvested from all areas planted to corn.

The cob fraction has potential for being harvested in the same pass as the grain and prototype equipment currently exist (Hoskinson et al., 2007; Shinners et al., 2007). Harvesting grain and collecting the cob fraction in a single pass reduces the potential for soil compaction associated with multiple field operations needed to harvest other residue components. Harvesting the grain and cob fraction would provide food, feed, and feedstock. Retaining the remaining residue would provide surface cover to protect against wind and water erosion and provide a source of biomass and nutrients for maintaining soil organic matter and sustaining soil biota. 


\section{CONCLUSIONS}

The biofuel industry is exerting a strong influence of corn production systems. In addition to using a significant portion of the grain produced, the feeding of byproducts to livestock results in the harvesting of corn residue. As cellulosic technology becomes available corn residue removal will likely increase. A major concern associated with crop residue removal is the potential for increased erosion. At this site, removal of corn residue reduced the time to initiate runoff and increased sediment loss. Residue removal did not affect runoff nutrient loss. Retention of the cob fraction of corn residue slightly increased the time to initiate runoff when the residue was dry. Removal of the cob fraction did not affect runoff, sediment, or nutrient loss at this site. The cob fraction may represent a crop residue component that can be harvested without negatively affecting the soil resource.

\section{ACKNOWLEDGMENTS}

U.S. Department of Agriculture, Agriculture Research Service, Northern Plains Area is an equal opportunity/affirmative action employer and all services are available without discrimination. The authors thank Dennis Francis, Steve Swanson, Jeff Shanle, Aaron Bereuter, Paul Korner, Luke Pesek, Chris Bauer, Susan SiragusaOrtman, and Susan Wagner for field and technical assistance and the Nienhueser family for access to their field.

\section{REFERENCES}

Andraski, T.W., and L.G. Bundy. 2003. Relationships between phosphorus levels in soil and in runoff from corn production systems. J. Environ. Qual. 32:310-316.

Blanco-Canqui, H., R.J. Stephenson, N.O. Nelson, and D.R. Presley. 2009. Wheat and sorghum residue removal from expanded uses increases sediment and nutrient loss in runoff. J. Environ. Qual. 38:2365-2372.

Bray, R.H., and L.T. Kurtz. 1945. Determination of total, organic, and available forms of phosphorus in soils. Soil Sci. 59:39-45.

Gardner, W.H. 1986. Water content. p. 493-544 In A. Klute (ed.) Methods of soil analysis, Part 1: Physical and mineralogical methods. 2nd ed. ASA, Madison, WI.

Gilley,J.E., S.C. Finkner, R.G. Spomer, and L.N. Mielke. 1986. Runoff and erosion as affected by corn residue: Part 1. Total losses. Trans. ASAE 229:157-160.

Graham, R.L., R. Nelson, J. Sheehan, R.D. Perlack, and L.L. Wright. 2007. Current and potential U.S. corn stover supplies. Agron. J. 99:1-11.

Halvorson, A.D., and J.M.F. Johnson. 2009. Corn cob characteristics in irrigated Central Great Plains studies. Agron. J. 101:390-399.
Hoskinson, R., D.L. Karlen, S.J. Birrell, C.W. Radtke, and W.W. Wilhelm. 2007. Engineering, nutrient removal, and feedstock conversion evaluations of four corn stover harvest scenarios. Biomass Bioenergy 31:126-136.

Humphry, J.B., T.C. Daniel, D.R. Edwards, and A.N. Sharpley. 2002. A portable rainfall simulator for plot-scale runoff studies. Appl. Eng. Agric. 18:199-204.

Johnson, J.M.F., R.R. Allmaras, and D.C. Reicosky. 2006. Estimating source carbon from crop residues, roots and rhizodeposits using the national grain-yield database. Agron. J. 98:622-636.

Johnson, J.M.F., M.D. Coleman, R. Gesch, A.Jaradat, R. Mitchell, D. Reicosky, and W.W. Wilhelm. 2007. Biomass-bioenergy crops in the United States: A changing paradigm. Am. J. Plant Sci. Biotech. 1:1-28.

Kim, S., and B.E. Dale. 2004. Global potential bioethanol production from wasted crops and crop residues. Biomass Bioenergy 6:361-375.

Lal, R. 2004. Is crop residue a waste? J. Soil Water Conserv. 59:136A-139A.

Littell, R.C., G.A. Milliken, W.W. Stroup, and R.D. Wolfinger. 1996. SAS system for mixed models. SAS Inst., Cary, NC.

Mannering, J.V., and L.D. Meyer. 1963. The effect of various rates on surface mulch on infiltration and erosion. Soil Sci. Soc. Am. Proc. 27:84-86.

McLean, E.O. 1982. Soil pH and lime requirement. p. 199-224. In A.L. Page et al. (ed.) Methods of soil analysis. Part 2. 2nd ed. ASA and SSSA, Madison, WI.

Mulvaney, R.L. 1996. Nitrogen- Inorganic forms. p. 1123-1184. In D.L. Sparks et al. (ed.) Methods of soil analysis Part 3: Chemical methods. SSSA Book Ser. 5. SSSA and ASA, Madison, WI.

Murphy, J., and J.P. Riley. 1962. A modified single solution method for the determination of phosphate in natural waters. Anal. Chim. Acta 27:31-36.

Perlack, R.D., L.L. Wright, A.F. Turhollow, R.L. Graham, B.J. Stokes, and D.C. Erback. 2005. Biomass as a feedstock for a bioenergy and bioproducts industry: The technical feasibility of a billion-ton annual supply. DOE/GO-102005-2135 and ORNL/TM-2005/66. Available at http:// feedstockreview.ornl.gov/pgf/billion_ton_vision.pdf (verified 15 July 2010). NTIS, Springfield, VA.

Rhoades, J.D. 1982. Soluble salts. p. 167-179. In A.L. Page et al. (ed.) Methods of soil analysis. Part 2. 2nd ed. ASA and SSSA, Madison, WI.

Shinners, K.J., G.S. Adsit, B.N. Binversie, M.F. Digman, R.E. Muck, and P.J. Weimer. 2007. Single-pass, split stream harvest of corn grain and stover. Trans. ASABE 50:355-363.

Smith, J.L., and J.W. Doran. 1996. Measurement and use of $\mathrm{pH}$ and electrical conductivity for soil quality analysis. p. 169-185. In J.W.Doran and A.J.Jones (ed.) Methods for assessing soil quality. SSSA Spec. Publ. 49. SSSA, Madison, WI.

Turhollow, A.F., J.W. Johnson, and J.H. Cushman. 1988. Linking energy crop production to conversion: The case of herbaceous lignocelluloic crops to ethanol. RERIC Int. Energy J. 10:41-49.

Varvel, G.E., and W.W. Wilhelm. 2008. Cob biomass production in the Western Corn Belt. Bioenergy Res. 1:223-228.

Wilhelm, W.W., J.M.F. Johnson, J.L. Hatfield, W.B. Voorhees, and D.R. Linden. 2004. Crop and soil productivity response to corn residue removal: A literature review. Agron. J. 96:1-17.

Wilhelm, W.W., J.M.F. Johnson, D.L. Karlen, and D.T. Lightle. 2007. Corn stover to sustain soil organic carbon further constrains biomass supply. Agron. J. 99:1665-1667. 